\title{
Antibacterial Activity of Leucaena leucocephala Leaf Extract Ointment against Staphylococcus aureus and Staphylococcus epidermidis
}

\author{
Tunik Saptawati, Novita Dwi Dahliyanti, Pradika Nudya Risalati Rachman \\ Pharmacy Department, Telogorejo School of Health Science \\ Jl. Arteri Yos Sudarso/Puri Anjasmoro Semarang
}

Submitted: 15-01-2019

Review: 09-03-2019

Accepted: 23-05-2019

\begin{abstract}
Practical experience shows that Leucaena leucocephala has long been used as a medicinal plant. The finely ground, crushed, or chewed leaves of this shrub are applied to the wound. This study aimed to determine the antibacterial activity of $L$. leucocephala leaf extract ointment against Staphylococcus aureus and Staphylococcus epidermidis. The extract was made by macerating L. leucocephala leaf powder in ethanol 70\% with $10 \%$ concentration. The research samples included seven (7) formulas of ointments with various $L$. leucocephala leaf extract (LLE) concentrations, namely F1 (0\%), F2 (5\%), F3 (10\%), F4 (15\%), F5 (20\%), F6 (25\%), and F7(100\%). Their antibacterial activities were measured from the diameter of the inhibition zone, which was formed because the administered antibiotics stopped the growth of $S$. aureus and S. epidermidis placed in Nutrient Agar medium. Gentamicin Sulfate ointment and Oxytetracycline $\mathrm{HCl}$ ointment were used as positive controls. The results showed that LLE inhibited the growth of $S$. aureus and S. epidermidis when prepared at concentrations of at least 20\% (F5) and 25\% (F6), respectively. The difference between the antibacterial activities of LLE $100 \%$ and Gentamicin Sulfate ointment was not significant. The capacities of LLE to prevent the growth of S. aureus and S. epidermidis were lower than Oxytetracycline ointment. These capacities express the antibacterial activity of LLE ointment against $S$. aureus and $S$. epidermidis, meaning that LLE can be used as a topical antibacterial agent.
\end{abstract}

Keywords: Antibacterial activity, Leucaena leucocephala, Staphylococcus aureus, Staphylococcus epidermidis

\footnotetext{
*Corresponding author:

Tunik Saptawati

Pharmacy Department, Telogorejo School of Health Science

J1. Arteri Yos Sudarso/Puri Anjasmoro Semarang

Email: tunik_saptawati@stikestelogorejo.ac.id
} 


\section{INTRODUCTION}

Herbal medicine is one type of treatments that are currently developed. In the case of infectious diseases, herbal remedies have become a positive aspect in the world of health, considering how, today, numerous types of bacteria can be immune to certain antibiotics. Accordingly, research is required to obtain supporting evidence and affirm the therapeutic effects of herbs.

One of the plants that can be applied as medicine is white leadtree, locally known as petai cina or kemlandhingan in Indonesia, with the scientific name Leucaena leucocephala (Lam) de Wit or Leucaena glauca. L. leucocephala is a shrub plant originating in Mexico and has now spread to many countries including Indonesia. Practical experience shows that it has long been used as a medicinal plant, for instance, by administering its finely ground, crushed, or chewed leaves to the wound (Hiwale, 2015; Devi et al., 2013; Latief, 2012).

Several studies have shown that L. leucocephala leaf extract (LLE) possesses several chemical compounds. Research using Thin Layer Chromatography (TLC) has proved that the ethanol extract of L. leucocephala leaf contains alkaloids, flavonoids, saponins, and tannins (Suryana, 2017). Another study with Gas Chromatography (GC) has identified the presence of terpenes, along with squalene as a secondary metabolite in LLE (Awe, 2013; Mohammed et al., 2015; Negi et al., 2016). Flavonoids, tannins, terpenes, and triterpene are known as phytochemical substances that have antibacterial properties (Aderibigbe, 2011; Mohammed et al., 2015; Negi et al., 2016; Zayed and Samling, 2016; Suryana, 2017). In other words, previous studies have confirmed that L. leucocephala leaf extract (LLE) has antibacterial properties.

Many pathogenic bacteria can infect the human body. Among them are Staphylococcus aureus and Staphylococcus epidermidis that cause skin diseases, such as impetigo, rash, folliculitis, acne, and sepsis in the surgical wound (Otto, 2009; Elliott et al., 2013; Harti, 2015). Testing the antibacterial activity of an ointment containing L. leucocephala leaf extract with various concentration against these two bacteria is therefore necessary, particularly to determine the appropriate level of extract in LLE ointment to treat the resulting infections efficaciously.

\section{MATERIALS AND METHODS \\ Materials dan instruments}

L. leucocephala leaf extract (LLE) was obtained from the maceration of L. leucocephala leaf powder taken from community plantations in Limbangan District, Kendal Regency. The maceration was carried out using ethanol $70 \%$ and left in a dark place while stirred occasionally for $3 \times 24$ hours (Hanani, 2014). The extract produced in this process was then made into ointment using white vaseline (vaselinum album) with varying concentrations, as presented in Table I. The tested bacteria, namely $S$. aureus and S. epidermidis, were acquired from the Health Laboratory Office in Central Java Province. These bacteria were planted in nutrient agar (Oxoid) medium, and the antibacterial activity testing of the LLE ointment with $0 \%$ to $100 \%$ extract concentrations was performed on them. Gentamicin Sulfate $0.1 \%$ ointment (generic) and Oxytetracycline ointment (generic) were used as positive controls.

Meanwhile, the instruments used in this study were laboratory glassware, mortar and pestle, laminar air flow chamber, autoclave, incubator (Memmert), oven (Memmert), and analytical balance (Ohaus).

\section{Methods \\ Formulation design and physical test for LLE ointment}

This study is a true experiment conducted in the laboratory using a randomized design for the formulation of LLE ointments with variations in the extract ratio. The composition of the ointments is shown in Table I. 
Table I. The design of the LLE ointment formulation

\begin{tabular}{|c|c|c|c|c|c|c|c|}
\hline Materials & F 1 & $\mathbf{F 2}$ & F 3 & F 4 & F 5 & F6 & F 6 \\
\hline $\begin{array}{l}\text { L. leucocephala leaf } \\
\text { extract (LLE) }\end{array}$ & $0 \%$ & $5 \%$ & $10 \%$ & $15 \%$ & $20 \%$ & $25 \%$ & $100 \%$ \\
\hline Vaselinum album ad & $25 \mathrm{~g}$ & $25 \mathrm{~g}$ & $25 \mathrm{~g}$ & $25 \mathrm{~g}$ & $25 \mathrm{~g}$ & $25 \mathrm{~g}$ & $25 \mathrm{~g}$ \\
\hline
\end{tabular}

\section{Physical test of LLE ointment}

In this study, the physical test of the prepared ointment included homogeneity and $\mathrm{pH}$. The cream was applied on a glass object, then rubbed and touched to find out its homogeneity. The $\mathrm{pH}$ test was performed using a pH meter and universal indicator (Widyantoro and Sugihartini, 2015).

\section{Preparation of antibacterial activity assay}

The antibacterial test of LLE ointment against $S$. aureus and $S$. epidermidis was carried out using the disc diffusion method (cup plate technique). The antibacterial activity was determined by measuring the diameter of inhibition zone-i.e., an area where bacterial growth is prevented, which was formed after incubation. S. aureus and S. epidermidis were poured into the nutrient agar medium. Then, a well was made in several places, and LLE ointment was filled into it. The medium was incubated at $37^{\circ} \mathrm{C}$ for $24-48$ hours. After incubation, the diameter of inhibition zone was measured (Radji, 2010; Mathur et al., 2013). Replication was conducted five times for each formula. Gentamicin Sulfate $0.1 \%$ ointment and Oxytetracycline ointment were used as both comparators and positive controls that received the same treatment as the LLE ointment samples.

\section{RESULTS AND DISCUSSION}

The maceration of L. leucocephala leaf powder produced a thick, brownish-green extract with a distinctive odor. Extracts with different concentrations $(0 \%, 5 \%, 10 \%, 15 \%, 20 \%$ and $25 \%)$ were then made into $25 \mathrm{~g}$ ointments with six different formulas and vaselinum album as the base. The ointments were dark brownish green and sticky with a distinctive smell. The color of the ointment comes from the color of the LLE. With a greater concentration of LLE, the color of the produced ointment was closer to that of LLE.

The $\mathrm{pH}$ test of each formula revealed a stable $\mathrm{pH}$ at 6 from the first to the fifth week. As for the homogeneity test, it showed that all formulas were homogeneous, as evidenced by their tactile quality, i.e., smooth feeling when touched, without any granules, and homogeneous color.

The observations showed that the $\mathrm{pH}$ of the LLE ointments was 6 from the first to the fifth week. This $\mathrm{pH}$ indicates that they are safe for use and will not cause irritation on the skin. An ointment is considered good when its $\mathrm{pH}$ is similar to the $\mathrm{pH}$ of the human skin, which is 4.5 to 6.5. The smaller the $\mathrm{pH}$ of the preparation, the more acidic it is, and the more it irritates the skin. Meanwhile, preparation with higher $\mathrm{pH}$ or alkaline condition can make the skin drier.

The antibacterial activity of LLE ointment against $S$. aureus was shown by the zone of inhibition in the nutrient agar medium, as presented in Figure 1. The LLE ointment started to inhibit the growth of S. aureus at a concentration of $20 \%$ (Figure 1 D). 


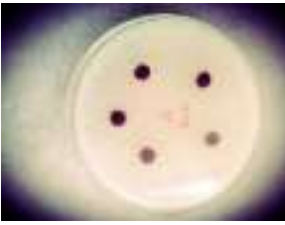

(A)

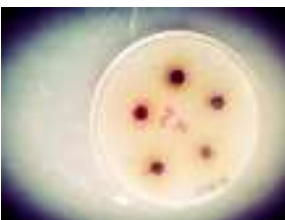

(E)



(B)

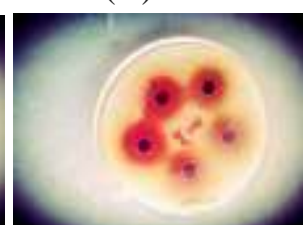

(F)

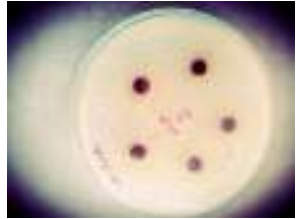

(C)

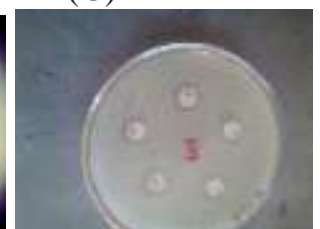

(G)

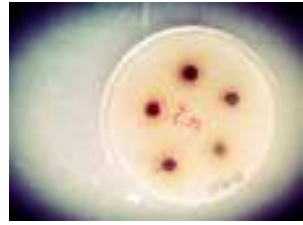

(D)

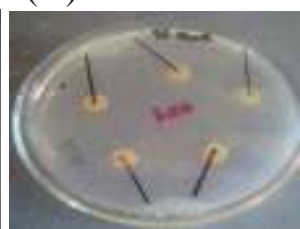

(H)

Figure 1. The Antibacterial Activity of L. leucocephala Extract Ointment against $S$. aureus
(A): $5 \%$ LLE Ointment
(B): $10 \%$ LLE Ointment
(C): $15 \%$ LLE Ointment
(D): $20 \%$ LLE Ointment
(E): $25 \%$ LLE Ointment
(F): $100 \%$ LLE Ointment
(G): Gentamicin Ointment $0.1 \%$
(H): Oxytetracycline Ointment

Figure 2 shows the antibacterial activity of the LLE ointments against S. epidermidis. The zone of inhibition started to appear in the nutrient agar medium when the dosage forms contained at least 25\% LLE (Figure $2 \mathrm{E}$ ).



(A)

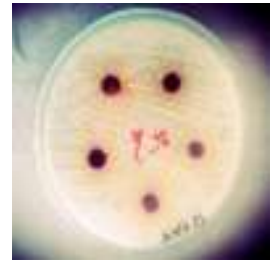

(E)

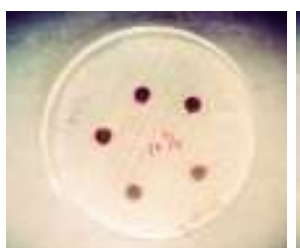

(B)

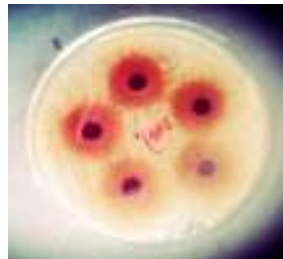

(F)
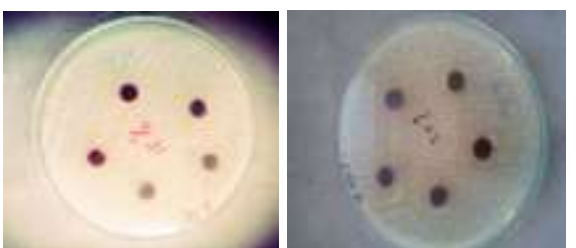

(C)

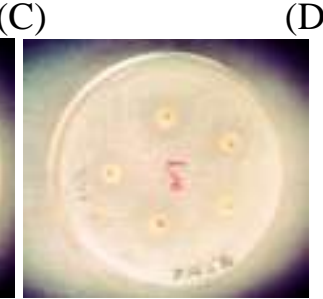

(H)

Figure 2. The Antibacterial Activity of L. leucocephala Extract Ointment Against $S$. epidermidis
(A): 5\% LLE Ointment
(B): $10 \%$ LLE Ointment
(C): $15 \%$ LLE Ointment
(D): $20 \%$ LLE Ointment

\begin{abstract}
(E): $25 \%$ LLE Ointment
(F): 100\% LLE Ointment

(G): Gentamicin Ointment $0.1 \%$

(H): Oxytetracycline Ointment
\end{abstract}

The antibacterial activity was determined by measuring the diameter of the inhibition zone. The measurement results for the inhibition of $S$. aureus and $S$. epidermidis growth are summarized in Table II. 
Table II. The antibacterial activity of LLE ointment against $S$. aureus dan $S$. epidermidis

\begin{tabular}{ccc}
\hline Samples & $\begin{array}{c}\text { The diameter of the } \\
\text { inhibition zone of } \boldsymbol{S} \text {. aureus } \\
(\mathbf{m m})\end{array}$ & $\begin{array}{c}\text { The diameter of the } \\
\text { inhibition zone of } \boldsymbol{S} . \\
\text { epidermidis } \mathbf{( m m})\end{array}$ \\
\hline & 0 & 0 \\
F1 & 0 & 0 \\
F2 & 0 & 0 \\
F3 & 0 & 0 \\
F4 & $12.70 \pm 0.45$ & 0 \\
F5 & $14.80 \pm 0.27$ & $10.60 \pm 0.55$ \\
F6 & $24.80 \pm 0.45$ & $22.40 \pm 0.89$ \\
F7 & $13.50 \pm 0.71$ & $23.80 \pm 1.60$ \\
K1 & $45.90 \pm 0.22$ & $16.20 \pm 0.45$ \\
K2 & & \\
\hline
\end{tabular}

Notes:

F1: 0\% LLE Ointment

F2: 5\% LLE Ointment

F3: $10 \%$ LLE Ointment

F4: $15 \%$ LLE Ointment

F5: 20\% LLE Ointment
F6: 25\% LLE Ointment

F7: $100 \%$ LLE Ointment

K1: Gentamicin Ointment $0.1 \%$

$\mathrm{K} 2$ : Oxytetracycline ointment

The results showed that the LLE exhibited antibacterial activity against $S$. aureus and $S$. epidermidis. It is indicated by the increasing diameter of the zone of inhibition as the concentration of LLE in the ointment increases. In other words, increasing the proportion of LLE in the ointment is likely to intensify the prevention of bacterial growth.

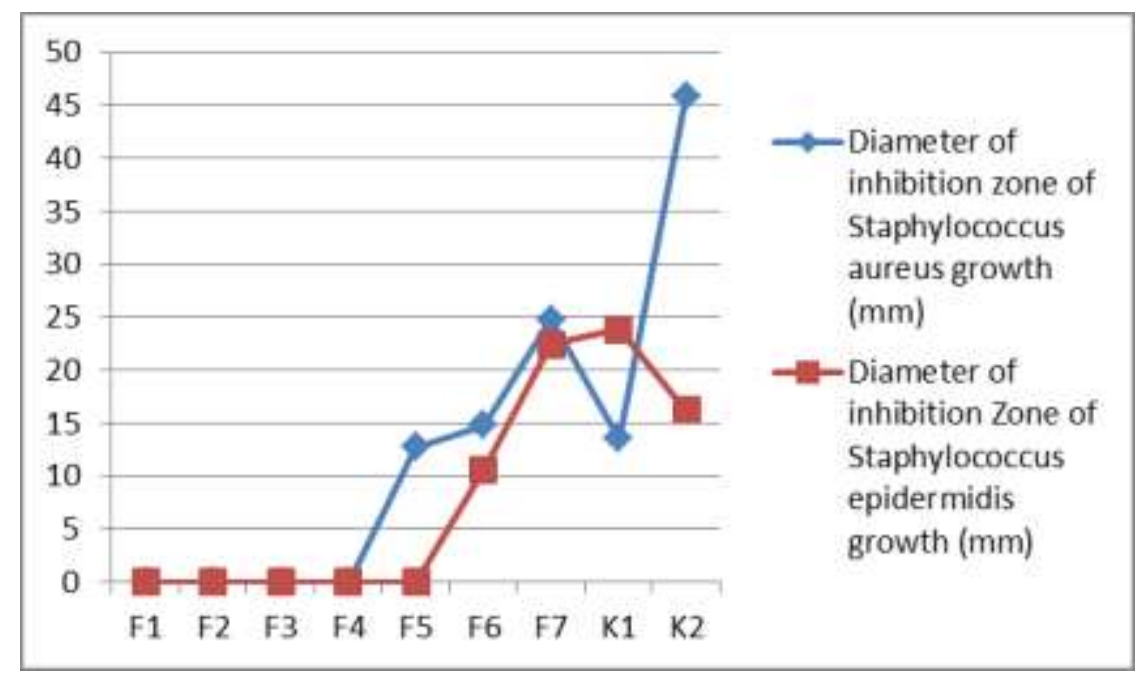

Figure 3. Graph of Diameter Inhibition Zone of $S$. aureus and $S$. epidermidis Growth by Antibacterial Activities of L. leucocephala Extract Ointments

Figure 3 shows that starting at a concentration of 20\%, LLE ointment can stop the growth of $S$. aureus bacteria with a zone diameter of $12.70 \pm 0.45 \mathrm{~mm}$. This inhibition intensifies with an increase in LLE content. At a concentration of $25 \%$, LLE ointment has a more significant inhibitory effect than Gentamicin ointment. The analysis of variance (ANOVA) produced $\mathrm{F}_{\text {ount }}>\mathrm{F}_{\text {table }}\left(\mathrm{F}_{\text {count }}=4811.293\right.$, 
$\mathrm{F}_{\text {table }}=2.87$ ), indicating differences in antibacterial activity between groups. The ANOVA was followed by a post hoc test (Bonferroni), which revealed that the antibacterial effect of 20\% LLE ointment was not significantly different from Gentamicin ointment (p-value= 0.112>0.05). Compared with Oxytetracycline ointment, the LLE cream results in lower bacterial growth inhibition.

The figure also depicts that the growth of S. epidermidis is inhibited by LLE ointment that has at least $25 \%$ extract concentration. In other words, below that level, the ointment cannot stop the growth of $S$. epidermidis. In pure LLE (100\%; F7), the bacterial growth inhibition is close to the antibacterial activity of Gentamicin ointment. The ANOVA on F6, F7, K1, and K2 produced $\mathrm{F}_{\text {count }}>\mathrm{F}_{\text {table }}\left(\mathrm{F}_{\text {count }}=\right.$ 184.583, $\mathrm{F}_{\text {table }}=3.24$ ), implying a statistically significant difference between the antibacterial activities of the concentration groups. The ANOVA was followed by a post hoc test (Bonferroni), which showed that the antibacterial effect of pure L. leucocephala leaf extract was not significantly different from Gentamycin sulfate $0.1 \%$ ointment $(\mathrm{p}$-value $=0.250>0.05)$. Compared with Oxytetracycline, the LLE ointment produces a lower bacterial growth inhibition.

The antibacterial activity of LLE ointment is caused by the ethanol extract of L. leucocephala leaf that contains secondary metabolites. Previous research has found that LLE comprises flavonoids, tannins, and saponins that have antibacterial properties (Suryana et al., 2017). Also, it possesses phytol (terpene compounds) and squalene (triterpene compounds), which are efficacious as antibacterial (Zayed and Samling, 2016; Suryana et al., 2017). This study has proved that LLE ointment with a minimum concentration of $20 \%$ and $25 \%$ can be used as an alternative topical treatment for the infection of $S$. aureus and $S$. epidermidis, respectively.

\section{CONCLUSION}

L. leucocephala leaf extract ointment has antibacterial activity against $S$. aureus and $S$. epidermidis when prepared with extract concentrations of at least $20 \%$ and $25 \%$, respectively. A further study is recommended to include testing on the antibacterial activity of LLE ointment against other types of bacteria and in different dosage forms and the ability of ointments in wound healing.

\section{ACKNOWLEDGMENT}

Authors would like to express the gratitude to Telogorejo School of Health Science, Semarang, for the support during this research.

\section{REFERENCES}

Aderibigbe, S. A., Adetunji, O. A., \& Odeniyi, M. A., 2011, Antimicrobial and Pharmaceutical Properties of The Seed Oil of Leucaena leucocephala (Lam.) de Wit (Leguminosae). African Journal of Biomedical Research, 14(1), 63-68.

Awe, F. A., Giwa-Ajeniya, A. O., Akinyemi, A. A., and Ezeri, G. N. O., 2013, Phytochemical Analysis of Acalypha wilkesiana, Leucaena leucocephala, Pepperomia pellucida and Sena alata Leaves. The International Journal of Engineering and Science, 2(9), 41-44.

Devi, M.V.N., Ariharan, V. N., and Nagendra, P., 2013, Nutritive Value and Potential Uses of Leucaena leucocephala as Biofuel - A mini review. Research Journal of Pharmaceutical, Biological and Chemical Sciences, 4(1): 515-521.

Elliott,T., Worthington,T., Osman, H and Gill, M., 2013, Mikrobiologi Kedokteran dan Infeksi, Penerbit Buku Kedokteran, EGC.

Hanani, E, 2014, Analisis Fitokimia, Penerbit Buku Kedokteran, EGC, Jakarta.

Harti, A.S., 2015, Mikrobiologi Kesehatan, Penerbit Andi, Yogyakarta.

Hiwale, S.,2015, Leucaena (Leucaena leucocephala). In Sustainable Horticulture in Semiarid Dry Lands: 291-299.

Latief, A., 2012, Obat Tradisional, Penerbit Buku Kedokteran,EGC, Jakarta. 
Mathur, P., Singh, A., Srivastava, V. R., Singh, D., and Mishra, Y. (2013). Antimicrobial Activity of Indigenous Wildly Growing Plants: Potential Source of Green Antibiotics, 7(29), 3807-3815.

Mohammed, R. S., El Souda, S. S., Taie, H. A. A., Moharam, M. E., and Shaker, K. H., 2015, Antioxidant, antimicrobial activities of flavonoids glycoside from Leucaena leucocephala leaves. Journal of Applied Pharmaceutical Science, 5(6), 138-147.

Negi, P., Rawat, B., and Negi, D., 2016, Antifeedant Constituents from Leucaena leucocephala. Journal of Applied Pharmaceutical Science, 6(12), 028-031.

Otto, M., 2009. Staphylococcus epidermidis--the 'accidental' Pathogen. Nature reviews. Microbiology, 7(8): 555-567.

Radji, M., 2010, Buku ajar Mikrobiologi: Panduan Mahasiswa Farmasi dan Kedokteran, Penerbit Buku Kedokteran, EGC, Jakarta.

Suryana, S., Nuraeni, Yen, Y.A., Rostinawati, Tina, 2017, Aktivitas Antibakteri Ekstrak Etanol dari Lima Tanaman terhadap Bakteri Staphylococcus Epidermidis dengan Metode Mikrodilusi M7A6CLSI, IJPST, 4(1): 1-9.

Widyantoro, O. B. and Sugihartini, N., 2015, Uji Sifat Fisik dan Aktivitas Ekstrak Daun L. leucocephala (Leucaena glauca Benth.) dalam Berbagai Tipe Basis Salep sebagai Obat Luka Bakar, Media Farmasi, 12(2), 186-198.

Zayed, M. Z., and Samling, B., 2016, Phytochemical Constituents of the Leaves of Leucaena leucocephala from Malaysia. International Journal of Pharmacy and Pharmaceutical Sciences, 8(12), 174. 
